\title{
Making a Difference. \\ A Comparative Philosophical Analysis of Difference, Death, Gaze and Enjoyment in Three Creation Myths from 19th-Century Slovenian Territory
}

\author{
Izar Lunaček
}

\begin{abstract}
The article takes as its starting point three creation tales recorded in the 19th century by pioneer ethnographer Janez Trdina in villages within what is today Slovenia to develop, through their comparison with myths from other parts of the globe (supported mainly by previous work done by comparative mythologist Zmago Šmitek), a philosophical basis enabling a deeper understanding of both their content and the standpoint of archaic thought in general. In dealing with the first story the article discusses the relationship between the sublime creator and his material creation along with the role of unconscious in forming the latter; the second tale is used as a basis of analysing the concept of relativism and the status of God's gaze; while a discussion of the third enables it to delve into the concept of God's absence in the world and the consequential human fate of death, toil and suffering as understood by the Bible on one and archaic mythology on the other side. The article hopes its exposition will contribute both to a deeper conceptual understanding of mythological material on the side of ethnology and trigger attention to the same material as a carrier of a noteworthy conceptual message on the side of philosophy.
\end{abstract}

Keywords: creation myth, philosophy, ethnology, legends, Slovenia.

As a professional philosopher, I feel that my discipline is sometimes inexplicably underrepresented or used in an overly simplified way within positive sciences in general and in ethnological studies in particular. I firmly believe that folklorists could resolve many merely apparent paradoxes in their source material through the use of the more rigorous conceptual analysis afforded by the oldest of theoretical disciplines. Philosophy, in contrast, often tends to treat folklore, mythology and other domains of ethnological research too freely, with a preconceived bias - either idealistic or dismissive - on how traditional societies conceive the world, without properly consulting the findings of those scientific disciplines officially devoted to the subject. The following article was written to at least slightly remedy that gap between the two disciplines by focusing on the specific topic of the creation of the world as we know it along with the relationship between man, God and the cosmos that stem from actual accounts of cosmogenesis recorded by ethnographers. It takes as its cue three creation myths gathered by the legendary 19th century pioneer of Slovenian ethnography, Janez Trdina, as quoted in his monographs by the comparative mythologist Zmago Šmitek, and extends the latter's comparison of them with other 
myths from around the world in order to discuss the differences between the properly philosophical worldviews of modern monotheisms and traditional folk beliefs. By doing so, its author hopes to contribute to resolving some theoretically tangled ethnological views on the worldviews held by folk beliefs and improving philosophy's understanding of the embedded beliefs of traditional thought systems.

The first of the three stories that I want to focus on was recorded in Šiška, a village in Trdina's time but today a borough within Slovenia's capital, a mere five-minute drive from the centre. It concerns the creation of Earth from an initial tripartite structure of God, sea and ocean floor:

There was nothing but God, the sea, and the sun. The sun burned hot. God got warm and dove into the sea for a swim. As He came back up, a grain of sand lingered lodged behind one of His nails. The grain dislodged and stayed on the surface of the water (for in the beginning everything stayed where it fell). This grain is our Earth, and the bottom of the sea is its homeland. ${ }^{1}$

The first noteworthy item in this tale is the concepts of the Earth's creation from a misplaced piece of ocean bedrock. This is not a novel concept, and many polytheist societies around the world conceive of the world as an entity dragged from the depths of the sea to the surface (see Šmitek's elaborate enumeration of some of them in ibid.). What interests me in this article as a philosopher, however, is the contrast of this with the most established creation myth in the modern West: the biblical report on creation from the first chapter of Genesis. There, the spirit of God is faced with an amorphous, watery mass and orders it, injects it with rational differences separating earth from water, and so on, in order to arrive at an ordered whole of the world as we know it today. In Trdina's folktale, in contrast, the world is not conceived of as a satisfyingly complete result of rationally and intentionally ordering an amorphous mass but rather features as a fragment brought unwittingly to the surface of the amorphous ocean that, incidentally, remains just as formless at the end of the tale as it had been before. While the biblical tale starts with the whole of the world as formless and with God as a rational force that structures it from the outside, Trdina's story sets up the initial state of the world as structured, and it does this by including God as one of its components. The tale begins with a clearly established tripartite form: God, the sun and the sea, while the subsequent creation takes place through a muddling of this structure: the bright, rational pole of the world represented by the pair of God and sun becomes over-saturated with itself and needs to seek refreshment via an immersion into Its opposite. The immersion is temporary and God returns to His place under the sun afterwards, but the momentary mix of opposites is impossible to forget or dismiss because it left behind a relic, a reminder, and this relic is the Earth, our human world as such.

The current state of the world, then, is here not conceived of as a result of God's reason completely, thoroughly, without a remainder ordering a primary amorphous mass but features precisely as a remainder, a fragmentary result of God's temporary abandon of His reasonableness and His immersion into His formless opposite. This has crucial consequences for the concept of the world, God and His antithesis as advocated by this folktale: if the Bible presents us with God as the absolute ruler that subdues His amorphous

1 Šmitek Zmago, Kristalna gora; mitološko izročilo Slovencev, Ljubljana: Forma Sedem, 1998, p. 11. 
opposite into order to create the world as the proof of His power over the abyss, God in Trdina's myth is seen as an entity unable to permanently keep to its own place, an entity internally split, in need of its own opposite for refreshment and unable to destroy the amorphous mass that survives Its immersion intact, while the world is conceived as a fragmentary relic of the two poles' temporary mixture that disturbs the purity of both. The human world, then, is not seen as a God-ordered whole but as a fragment that mars the initial order and testifies to the incapability of its elements to keep discretely to each other.

This status of the human world as a fragmentary disturbance of an initial order is one crucial difference between this myth and the Bible. The other, already hinted at above, is the unintentional nature of God's creation of it. In his book, Šmitek compares the tale to other myths from across the globe where Earth is similarly created as a glitch in the initial duality of the world via God's interference, but the operation is usually carried out intentionally and through the use of tools or helpers. Thus, in some cases, God drags the Earth from the bottom of the sea with a fishing rod or other instrument; in others, He sends animals to retrieve it, and in still others transforms into an animal Himself to dive for it. ${ }^{2}$ While all these stories conceive of the Earth as a hiccup in the world's initial structure, the divine creator continues to be a fully conscious planner of this jab at order. Furthermore, while the gods of these other stories apparently do acknowledge the need to combine reason and amorphous, fluid matter in order to arrive at creation, they stay largely untouched by the mix, using other, lower beings or objects as instruments for the Earth's retrieval: even when they transform into animals themselves, it could be argued that this merely enables them to leave their divine essence untouched by their other. The myth recorded by Trdina is then singular in conceiving of the creator not as someone who rationally realises the necessity to blend disparate elements in the world's creation, and then elects to send a senseless creature or tool to do the dirty work for Him but as an entity internally split itself, oversaturated by His own essence and diving into His opposite for refreshment with the world as a mere unplanned by-product of His temporary inner splitting and self-abandon.

While this might suggest that our myth presents a chance anomaly or even a fabrication that can be disregarded, similar material provided by other myths from across the globe suggest otherwise: the world teems with tales of unconscious and outright silly creators who contribute to the current state of the world unwittingly and by pure coincidence. The prime examples stem, not surprisingly, from studies of trickster deities: Wadjunkaga, for example, the trickster of the North American Winnebago tribe described by Paul Radin in his pioneering study of the mythic archetype, ${ }^{3}$ is precisely such an internally split deity who cannot fully control his own bodily organs (his hands cut meat and their owner of their own accord, his penis surprises him with an unplanned morning erection and subsequently separates from his body to carry out solo excursions, etc.) and who creates the current state of the world, ranging from crucial social prohibitions to local flora completely unintentionally, in the course of pursuing his own personal goals, habitually centred on eating and copulation.

Wadjunkaga is by no means an isolated example. Within North America, the Tlingit trickster Raven is said to have created the Great Lakes of North America by stealing water

\footnotetext{
2 Ibid., pp.12-14.

3 Paul Radin: The Trickster, A Study in American Indian Mythology, New York: Schocken Books, 1972.
} 
from the stingy ethereal bird Petrel and accidentally spilling onto the ground the excess his beak could not carry. ${ }^{4}$ In an analogous episode, the West African trickster Ananse, a spider featured in Yoruba folktales, is said to have once hoarded all the wisdom of the world into a container only to drop it while attempting to hide it up a tree: the container broke thus providing pieces of wisdom for humanity. ${ }^{5} \mathrm{~A}$ third almost identical example comes from a folktale told among African Americans at the beginning of the 20th century and collected by Zora Neal Hurston: in this scenario, God initially makes humanity soulless and makes it wait for ages before He furnishes them with animae since He is eternally dissatisfied with 'the dryness of their clay': it takes a Jew to steal the entire mass of soul from God's pantry and inadvertently spill the fragments on Earth where each human gets at least a bit of it. ${ }^{6}$

All of these stories basically discuss the same dilemma as Trdina's Šiška myth but this last one expresses it the most poignantly: the specific mix of the godly and the material specific to the human world cannot be planned by an utterly super-rational being a being of pure rationality would necessarily postpone the bridging of the gap between the two areas forever - it takes a foolish hero, someone ready to simply jump the gap and take on the impossible task of containing the godly within a mortal shell to actually create the uneven, unfair, fragmentary and rationally unplannable mix of the two that makes up humanity as we know it. The tale recorded by Hurston can, additionally, be read in two ways: one, in which the impatient, gluttonous trickster is blamed for the imperfect state of the world with only uneven fragments of soul available to humanity as opposed to a more just distribution of soul by God, and another in which it is clear that God is unable to fulfil the task of soul distribution at all (he would simply be postponing it forever), and the trickster's action resulting in an arbitrary, fragmentary distribution is the only solution for mixing soul and shell available with its fragmentary, 'unjust' and uneven nature possibly even accounting for positive aspects of the current state of the world such as enjoyment defined precisely by imbalance, fragmentation and ecstatic spilling of soul over the borders of the body. Trdina's myth quoted at the start of this section could be seen as making a similar statement: if God wants to create the world completely by Himself, without hypocritically outsourcing the dirty work to other aspects of Himself posing as animals or tools, He needs to become internally split, oversaturated with Himself and immersed in His own opposite, creating the world unintentionally and in the form of a chance fragment belonging to an unseen, possibly even inexistent whole.

This, of course, is a highly radical conclusion that most organised faith systems will want to avoid, preferring that God keep His rationality and extra-worldly status by outsourcing unpleasant aspects of creation to other entities as seen in the alternate versions of the diving myth above. Some versions of this myth quoted by Šmitek actually feature not merely a neutral tool or an animal as God's secret agent but actually cast the Devil in that role, literarily demonising God's excursion beyond His confines in creation. The entire tradition of presenting the Devil as a simia dei, God's monkey/imitator, is set

\footnotetext{
4 Radin, ibid., p 104.

5 Christopher Vecsey: 'The Exception Who Proves the Rules - Ananse the Akan Trickster', in: Hynes, William J. \& Doty, William G. (eds.): Mythical Trickster Figures - Contours, Contexts, Criticisms, Tuscaloosa \&London: University of Alabama Press, 1997, p.117.

${ }^{6}$ Campbell Reesman, Jeanne: Trickster Lives: Culture and Myth in American Fiction, Athens \& London: University of Georgia Press, 2001, p.x.
} 
along the same lines, with the Devil mimicking God's actions during creation but, due to His suggested incompetence, creating phenomena perceived by humanity as negative while God is the one responsible for good things. A perfectly identical structure can be found, interestingly, as far away as in a Melanesian creation myth in which the creator has a foolish brother who mimics his actions to create less desirable versions of his sibling's work: where the creator makes fish, his brother makes the shark; where the creator produces women, his brother makes ugly women, etc. ${ }^{7}$ A similar relationship closer to Trdina's myth is to be found among the ancient Greek Titan brothers: Hesiod ascribes to Prometheus, the creator of man and bringer of fire, a sibling called Epimetheus who, in turn, foolishly opens Pandora's box and lets loose all the troubles of the world. Again, this sort of splitting enabling one to ascribe all the positive aspects of creation to an idealised entity while projecting those one finds unpleasant onto its dark twin, is unheard of in cultures featuring proper trickster gods who embody precisely this complementary nature of delight and error, of enjoyment and suffering: the Raven is a creator of men and bringer of water in a way that makes him comparable to Prometheus, but his positive feats are often carried out inadvertently and for selfish reasons, while some of his other adventures conclude with the bringing of death or diseases onto Earth, much like the opening of the box attributed by Hesiod to Epimetheus. It is possible that this sort of more complex nature was also held by Prometheus at some point since Epimetheus is likely to be Hesiod's invention, along with the etymology of the two brothers' names: 'Prometheus' means looking forward and 'Epimetheus' looking backward, suggesting a difference between rational planning in advance and unwitting feats that can only be analysed post factum, while some researchers have suggested, by drawing parallels with the Sanskrit pra matha, to steal, that Prometheus' name originally merely meant 'thief', cutting the cord of his name to rational planning and possibly reconnecting the Titan with the amoral, border-crossing, heedless-of-consequences nature of trickster deities from other parts of the globe.

For one final turn of the screw in this segment of the article, let us briefly turn to a myth from the Polynesian Tikopia as quoted by Levi-Strauss in the first volume of his Mythologiques. It is a story that starts with a feast organised by gods still living on a paradisical Earth, attended by un uninvited 'foreign' god: the divine stranger steals the entire contents of the feast and flees with them to heaven but drops four items of food during his escape: it is these four items that provide the totems for the current clans of Tikopians ${ }^{8}$. The story is almost identical to those recording Raven's, Ananse's or the Jew's feats with water, wisdom, and soul (the thief steals an abundance of goods hoarded by the gods and spills some of them for human use) but the trickster's movement in the Tikopian myth goes in the opposite direction: from Earth towards the heaven. The difference is small but radical: if Raven can steal be credited with, albeit inadvertently, providing humanity with fragments of heavenly goods, the foreign god in the Tikopian myth transports earthly goods into heaven, leaving humans with only fragments of the original whole. The insistent analogy of this version of the trickster tale to the usual ones featuring the opposite direction, however, merely shows that traditional thought conceives of the initial whole as completely phantasmatic and its original location unimportant. That is to say,

\footnotetext{
7 Campbell, Joseph: The Hero with a Thousand Faces, Novato: New World Library, 2008, p. 250.

8 Levi-Strauss, Claude: The Raw and the Cooked, Mythologiques, volume one, Chicago. University of Chicago Press, 1983, p.53
} 
the point is not that humans have access to fragments of a whole that would otherwise be unavailable to them but that they have access to fragments - it is fragments, as such, that matter and are preferred to both nothing and the whole since they are the ones that enable, in the same breath, both the symbolic structure and enjoyment so typical of humanity.

In short, what all the stories enumerated in this segment seem to suggest is that the image of a paradisical, perfectly rationally ordered state of the world is illusionary: the human world as such is fragmentary and unbalanced and it is these qualities that enable both its positive aspects (language, culture, enjoyment) and its negative ones (death, disease, toil); moreover, it is a state brought about by an unintended action of an internally split creator. While many cultures still tend to ascribe the negative aspects of being to a malevolent adversary of a good and rational God, others view them as mere bumbling of an idiot brother or even of a necessary, ambivalent trickster inseparable from the good God: the latter is the case with Ananse and certain North American tricksters holding the closest of ties with the chief deity in their respective pantheons. Trdina's myth, however, is unique in abandoning the need for any such duality altogether: God is here, so to speak, cast as His own idiot brother or court jester; it is God Himself that cracks up and dives into His opposite to create the world as an accidental fragment, and that is a unique account of creation definitely worthy of marking and possibly describable as the inadmissible truth of all other accounts.

I want to analyse the second story from Šmitek's quotes of Trdina, which develop this same theme further and will let us reflect on some additional themes. This one was recorded in Mengeš, today a town not far from Ljubljana, and it goes as follows:

In the beginning, there was nothing but God and God slept and dreamt. The sleeping and dreaming had been going on forever. But it was fated that He should awake. He awoke and looked about, and each of His glances turned into a star. God wondered at this and began to travel to see what He had created with His eyes. He travelled and travelled, but there was no end in sight. On His way, he also passed our Earth. But He was already weary at this point: sweat stood on His brow. A bead of sweat fell on the Earth, and the bead came alive and this was the first man. ${ }^{9}$

This story partly broaches the same subject as the first: unwitting creation. As in the Šiška tale, here too God creates the world with no rational intention, only this time it is merely by looking around. His creation surprises Him, and it is suggested that He cannot rationally process everything He continuously creates, because even by observing the created world He merely creates more and more of it, never coming to an end, never catching up to His creation with a conscious processing of it. Creation is thus here again presented as an unintended, unconscious process that cannot be trapped in the web of rational planning and processing. However, what is additionally interesting in this story is the creation of man placed precisely in this gap between God's comprehension and His creation. His own creation gets the better of God; it exhausts him and, as an equally unintentional admittance of powerlessness in the face of his own creation, God literarily secretes man.

${ }_{9}$ Šmitek, ibid., p. 17. 
Placing man at this crossroads between God and His creation is not a concept unknown in classical Bible studies. According to Christian doctrine, God does create man precisely as an excess of creation, as the one thing in creation that does not bend to His will automatically. God's creation of man as a being of free will that can choose to follow the way of God or reject it is God's ultimate proof of power: God is seen as so omnipotent that He can risk making a being able to resist His will, and if that being chooses God's way instead of the Devil's this free choice of the good renders it so much worthier. In our story, however, man is not only created at the point where God can no longer control His own creation, but also at the point where God can no longer control Himself and secretes sweat haphazardly. The God of this story is not a God who rationally created the world and is able to see and control all of it and who then adds, as a challenge, a being able to resists His will. No, it is a God who accidentally creates the world with His eyes, wonders at His own powers, fails to process even the dumb matter that He had created, simply because there is such an abundance of it and then unwittingly secretes His own tiny double, most probably to the amazement of both. Creation exhausts God, but not the act of creating it as such (that exhausted the God of the Bible so much he had to rest for a day); no, this is easy, this happens automatically, merely by looking about, but the comprehension of it is physically so exhausting that God spills over His own borders, sheds a fragment of Himself and creates man as His own living excreta. God and man are equally humiliated in this story: God is merely a childlike, freshly awoken, ingenious idiot with an uncontrollable superpower of effortlessly creating infinite worlds, incapable of taking in everything $\mathrm{He}$ so easily spurts out, while man is far from the crown of creation, but a mere automatic secretion of God's glands, a fragment of God dropped when exerted, when His own creation proves quite physically beyond Him.

A second aspect of this story that is highly interesting is the twist it puts on the old philosophical story of relativism and partial points of view. The traditional, metaphysical stance on the issue is that men are necessarily carriers of a partial view of reality: we can never fully take it all in. We can, however, tend towards a more complete comprehension of reality through the use of methods that tap into a more objective plane: it then depends on the system of thought what that more objective plane is: whether it is literarily the mind of God whose point of view is absolute or simply a symbolic system of abstract notions, such as Plato's world of ideas or the regulative idea of complete knowledge postulated by modern science, and whether we can tap into it with the use of reason or with more intuitive methods as in the case of religious mysticism. Twentieth century thought, however, increasingly negated any independently existent objective plane, resulting in the popular post-modernist notion that the only thing that exists are partial points of views that can never be integrated into an objective view of reality. Every point of view is valid, none more than another, and we should not force our points of views onto other people's - so goes the chant of the current relativism - disabling even constructive criticism of everyday ideologies as long as everyone believing in them is a consenting adult and does not try to impose them on others. The post-structuralist line of thought presented by the Slovenian Lacanian school has been, in my view, challenging this notion in a very intelligent manner, by claiming that a belief in one's point of view as 'merely partial' always hides a belief in an 'objective view' existing someplace else (in relation to which my point of view can be seen as partial) and that such a stance is much more prone to supporting dangerous ideologies than if we take the plunge, admit the insistence of a formal, content-free 
Real and attempt to refine our points of view by engaging with it, by 'tarrying with the negative', never getting an easy guarantee that we are on the side of the 'right God' by an authoritative external institution. In this conceptual structure, every point of view can engage with the Real, and the clashes among different points of view should not be discouraged, because it is precisely in the paradoxes emerging in these clashes that the Real is most likely to manifest itself.

Now, the interesting thing that happens in our story is that it does not deny the existence of God; it starts with God as the only reality there is albeit it is a God that does nothing but sleep; not an all-knowing but a dreaming God; a God whose consciousness is still unconscious, a mere jumble, associative slide of signifiers (empty signifiers, presumably, since the world has not been created yet, providing God with no concrete material from His waking life to give content to His dreaming). As God awakes, His very glance creates the world but He has no idea what He has created and has to exert physical effort to process even a part of it. Here, then, we have this quite postmodern notion that the world does not exist outside of my glance, outside of a specific point of view on it, but this notion is, firstly, expanded to include not only men but also God as the usual carrier of the absolute glance. Secondly, the world created by His glance is always slightly bigger than its carrier's own understanding of it. Thirdly, man as the normal carrier of the partial glance is created right in this gap between God's creating glance and his processing of it, so the lesson to be learned from this story regarding relativism might be the following: yes, men are carriers of a merely partial view onto the world, but if God existed (and we can suppose He exists at least in the sense of something that generates the world we live in and unwittingly secreted us as the carriers of our own partial glances) He would be absolutely no better at processing creation. Thus, we may regard our own partial glances as active acts of creation, making us responsible for what our points of view stand for (unable to hide behind the 'well, it's just the way I see things, nothing I can do about it' excuse) and, simultaneously, acknowledging there is always something more, some bit of the Real in our points of view that forever eludes our processing, making it all the more vital to think about what we stand for since our points of view inevitably spread beyond the confines of our consciousness, affecting other people in ways that we cannot fully predict.

Finally, what this myth tells us is that the Other, although powerful enough to create the world we live in, does not have control over His creation nor fully understands it, and that we are as much a confusing answer to His dilemma as $\mathrm{He}$ is to ours, which does not, however, mean we do not have to hold Him accountable for what He has created. In other words, the Mengeš tale seems to illustrate perfectly a central point of theoretical psychoanalysis (aka the post-structuralist Lacanian school of philosophy): the Other is an assumption we cannot simply do without, and He has effects even if He is arguably fictitious and arguably our own product, but His subject's quest to find an answer to our own incompleteness in Him is always fated to result in facing up to this same lack of completion at the heart of the Other Himself (the practical psychoanalytic process is also based on this insight: analysis can only start if the patient conceives the analyst as 'the subject who is supposed to know' but the analysis by the patient encountering this irreconcilable lack in the analyst as well, the entire process having been motored by the false projections of transference, but that have, however, produced very real results in the patient's mental health). 
The third and final Trdina story I want to examine in this article is set after creation and merely concerns the coming-about of the state of the world we currently live in but is also able to pose many interesting questions about the topics opened above. This one unfolds in the following way:

In the beginning, the earth was barren from end to end, all rock. It bore no fruit, but there was also no need for it to do so. God Himself lived among the people in mind and body, feeding them with heavenly manna. But the people were unhappy for they feared God's might and splendour. From the constant trembling, they could neither enjoy eating nor drinking, nor take leisure at their will. God felt sorry for them. He separated from His body and moved to the heavens. His body rotted away on the earth and turned into fertile soil. In the godly soil, the people now sought out food for themselves and no longer needed the heavenly manna. And it was only now that they began to enjoy life and be happy. ${ }^{10}$

Although the content of this story might well have been partially inspired by the social context of Slovenian life in the 19th century (romantic tendencies for independence had just begun to blossom and the tale could be read as a plea for sovereignty from the protective yet stifling fatherly figure of the Austro-Hungarian empire), its diametrical opposition to the biblical account of the fall is both sufficiently striking and paralleled with stories from other parts of the globe to deserve analysis as the symptom of a more general and social-context-free aspect of traditional thought. In the Bible, the separation of God and man, which includes the introduction of 'tilling the soil', is presented as a tragic state of affairs, a mistake on man's part edged on by a diabolical tempter; it needs to be atoned for and it is suggested as man's ultimate goal to be reunited with God in the afterlife. Not so in the tale recorded by Trdina: the cohabiting of God and man on a preFall earth is not seen as paradisically fruitful and blissful but as barren and stifling for man's state of mind, and the separation of the two is not presented as man's error but as God's premeditated decision in His offspring's favour. This take on difference, although so radically different from the traditional European view on Fall from grace propagated by official Christian doctrine, is in full concordance with the theories on enjoyment offered by modern philosophers of the above-mentioned Lacanian provenience: Alenka Zupančič, for instance, in her monograph on comedy, explicitly demonstrated how castration is not the disabling but the enabling of enjoyment; how enjoyment can come about only after a cut into an initial whole creating a phantasmatic 'lost object' that desire seeks eternally to attain but that drive can forever orbit, generating enjoyment ${ }^{11}$. Enjoyment, in other words, is possible only with distance, with a certain lack incised into a primordial whole, and Trdina's story confirms this theoretical stance perfectly.

This, again, is a view in no way confined to this mythical story: it has parallels in folk and tribal tales found throughout the globe. An ancient Babylonian tale, for instance, paints the beginning of time as an eternal embrace between Sky and Earth that constantly conceives children but does not provide them with a space into which to be born. Finally, one of the children, a god called Enlil, pushes the divine parents apart, creating the human

\footnotetext{
${ }^{10}$ Šmitek, ibid., p.16.

${ }^{11}$ Zupančič, Alenka: The Odd One In, London: MIT Press, 2008, pp. 191-3.
} 
world as the purely negative, insubstantial room opened between Sky and Earth where life is allowed to flourish. ${ }^{12}$ This story is congruent with ours on the point that 'Heaven on Earth', as the popular Christian phrase goes, is not a concept to be longed for but a closed circuit of eternal copulation that bears no fruit: heaven needs to keep its distance if life is to find a place for itself and 'Heaven on Earth' can be equalled to a catastrophe (a falling of the sky) of cataclysmic proportions. Enlil's role is thus similar to that of the titan Atlas in Greek mythology who is also the keeper of the difference between heaven and earth; he is reduced to an unimportant character in modern versions of Greek mythology, but it would be fascinating to explore what his folkloric origins are.

Perhaps even more interestingly, the ancient Greek concept of Chaos, that we today view as the image of utter disorder, is described in Hesiod's accounts as pure negativity that is the only entity present at the beginning of time and that finds its fate, in the act of creation, not buried underground or banished beyond the cosmos' confines but installed between Heaven and Earth as the void keeper of their difference. Chaos, in other words, is originally a figure of negativity that structures, orders the world, which is the very opposite of how we understand it today. With this in mind, it is interesting to take one more look at the Bible's book of Genesis, in which, it seems, two separate accounts of creation are offered that could account for this split view of difference found in modern Christianity.

The first chapter of Genesis begins with the image of an endless, formless mass of water that is subsequently ordered by God's spirit precisely via the operation of separation: waters are separated from land, day from night, and so on. The second chapter then begins with an already ordered world into which a negative difference is injected: a difference between God and man that opens Pandora's box, so to speak, and lets out pain, death, toil and suffering, ending man's bliss in Eden. Interestingly, however, this diabolical difference comes about through man's attempt to abolish the difference between himself and God (the serpent's phrasing is that eating from the tree will make humans equal to God), so it could be said that the point of the biblical story is that we should respect the differences set up by God or we will be punished with the most radical difference of all, death and consequently suffering (enjoyment being wisely hidden from the equation and only hinted at by subsequent popular associations between the fruit and enjoyment).That we are dealing with two separate stories in this part of the Bible, talking about two different concepts of difference, is also partially hinted at by the fact that man is created twice, once at the end of the first chapter and then again in the second, suggesting the Scripture here fuses two separate accounts perhaps stemming from two original regional folk tales.

As an interesting side note to this line of thought, we should mention that St Augustine authored an influential monograph on marriage and lust in which one of his main points was that man would have indeed become equal to God after eating from the tree of knowledge if God had not punished him with lust, i.e. with an inability to control his reproductive organs, splitting man from within and making him incapable of keeping his carnal desires at check; presumably, man before the Fall could copulate rationally and intentionally. ${ }^{13}$ Man's rebellion against God, then, is seen by one of the most influential Christian thinkers as punished with its micro-repetition: by providing man with his own sexual organs as internal rebels against his rational will, a problem that God apparently does not share with humanity.

\footnotetext{
${ }^{12}$ Campbell, Ibid., p.243.

${ }^{13}$ St. Augustine: On the Good of Marriage and On Marriage and Concupiscence, Amazon Kindle edition, 2010.
} 
Taking the shape of both the snake and the tree of knowledge into account, however, it is possible to draw a parallel between psychoanalytic theory and the story of the Fall and suggest that man's eating from the tree of good and evil is to be read as an infant's attempt to simultaneously gain access to his mother's forbidden parts, reserved for the father (the fruit), and assume the place of the father by taking possession of his symbol of power, the phallus (the tree). If we may interpret the tree of knowledge of good and evil as God's phallus, then the snake is an even more obvious candidate for the role of the same phallus' treacherous side, acting against its carrier's will, so, in this interpretation of the story, it would effectively be an uncontrollable aspect of God's own body that talks man into transgressing the former's rational carrier's prohibition. Thus, if we follow this interpretation of the biblical tale, the Fall actually does succeed in equating man with God: growing up, becoming the father, means precisely attaining the status of a symbolic, sexual, internally split being with independent organs of enjoyment; the heavenly Father possesses them as well and merely hides this fact from His children, demonising the tempter-phallus as His independent adversary. This twist would thus enable us to view the Fall as a perfectly normal story of coming of age that is simply infused with a tragic light by the false vision of a parent perfectly rational and perfectly in control of both the world and His body that makes the subsequent fate of His children (working, suffering, enjoying, reproducing) seem lacking where it actually is not. Trdina's story is much more coherent in this aspect, equating emancipation from God with liberty, leisure, and enjoyment just as much as independent work.

One final folktale that I want to recount here and that handles the same issues in a very constructive manner comes from the West-African tribe of Fon, which describes the clash between their pantheon's trickster deity, Legba and his mother, the female godhead Mawu. In this story, Mawu starts her career by residing not quite on earth, as is the case with many gods at the beginning of time, but still quite near it, only a few feet above ground, setting her apart from her realm but still enabling her direct reign over it. Like the gods in less radical variations on the diving myth discussed at the beginning of this article, Mawu exerts her power over creation through an outside tool: her son Legba who carries out her every command. Mawu supplements this outsourcing, however, with a cunningly moralist note that is worthy of a modern dictator: everything bad that happens to humanity from the machinations of the mother-son team is blamed on Legba while all the positive effects are ascribed to Mawu. Legba eventually tires of being his mother's errand boy and scapegoat and proceeds to get the message across to his levitating parent by the symbolic gestures of splashing her with dirty water left over from washing his laundry. Mawu eventually takes the hint, realises that maintaining control over her creation will always rise or fall in equal measure to her getting her hands at least slightly dirty, so she opts for a complete retreat from active business: she moves to heaven and greatly lessens the grip on worldly affairs that are taken care of more or less independently by Legba who is now seen by humans as an ambivalent and no longer merely as an evil agent, while Mawu assumes the role of a completely transcendent deity who has nothing to do with good or evil at all. ${ }^{14}$

\footnotetext{
${ }^{14}$ Quoted in: Lewis Hyde: Trickster Makes This World - Mischief, Myth and Art, Edinburgh: Cannongate, 2008, pp. 173-4.
} 
The Fon myth is remarkable for many reasons: one of which is the fact that it traces the evolution of modern monotheism backward. It starts what we could describe as the hidden truth of ideology (including modern monotheism) in which the nominal ruler pulls all strings but never gets her hands dirty and accepts merely the positive effects of his endeavours while pragmatically projecting the aspects her subjects perceive as unpleasant to a specially designated, demonised scapegoat carrying out orders. This, incidentally, is what Plato, widely considered to be a crucial contributor to establishing the concept base of modern European monotheism, pragmatically suggested as the only possible option of his ideal state's belief system: God should only be credited with the good and not be depicted as an ambivalent entity like in Homer's epics whom Plato considered vulgar and counter-productive for the moral education of citizens (Plato: The Republic, par. 380c).The Fon myth, then, starts by following Plato's proposition, and goes on to find it intolerable, preferring in conclusion the division between an ambivalent trickster regulating worldly affairs and a merely formal trans-worldly deity keeping a phantasmatically referential place in the beyond, much in the way God's departed spirit provides a reference for human's enjoyment in a world marked as incomplete by lacking that same spirit in Trdina's third tale, or the way that the missing cornucopia of divine goods provide a reference for the fragments that enable enjoyment in the tales featuring Raven, Ananse and the Tikopian trickster in the beginning.

In all these examples, then, the main difference between the official ideological stance of modern monotheism and that of traditional belief systems seems to be the following. Monotheisms equip the phantasmatic sphere beyond the physical world with concrete content (like moral superiority, for instance, but maleness, justice, and even preferences for certain ethnic groups or sexual practices can easily get on the list once the gate for concrete content is open) and are thus also more ready to idealise it and dream of its transformation from fantasy into reality ('Heaven on Earth', again) conceiving the present state of the physical world as disappointingly incomplete. In contrast, traditional belief systems, at least judging from the tales included in this article, appear to conceive the same transcendental sphere as merely a formal, vacant place-keeper that also enables the world here and now to be seen as lacking and incomplete, but this lack and incompletion are seen as ambivalent: enabling constant change, evolution and enjoyment, along with work, death and suffering as the positive trio's darker companions that, however, are inextricable from them: true enjoyment, by rule, skirts the border with pain, comes about by an engaged investment of energy, and shines brightest outlined against the background of death. In general, I believe it is possible to assume that folk and tribal tales of creation have a very nuanced and complex attitude towards lack and difference: cuts into an initial whole are evidently seen by much of this material as something absolutely necessary to be both established and constantly bridged in order for both symbolic forms and enjoyment to come about.

The symbolic, incidentally, is also a concept that combines gap and connection: its original meaning comes from 'to link', while Lacanian thought has long sought to complement this function by stressing the severing, disruptive, whole-shattering aspect of the symbolic. Trickster figures have a similar history: they have habitually been deemed beings of the liminal by the authors of the best-known monographs on the issue, but I was especially grateful for Lewis Hyde's more recent warning that the trickster's in-between status not only entails crossing gaps between separate domains but also includes creating 
them. Hyde muses on how tricksters traditionally do inhabit the very space between heaven and earth, acting as semi-independent, morally ambivalent messengers of the heavenly deities, but that this should not blind us to parallel accounts of tricksters as the originators of the very distance between heaven and earth that they only later become employed to cross. ${ }^{15}$ If we disregard this aspect of the trickster phenomenon, and this is my own addition to Hyde's warning, we risk seeing the trickster as an obscure phenomenon residing in unclear, misty areas where divergent domains blend into one another, leading us to succumb to the New Age trap of celebrating traditional thought as an escape from the analytical, rational approach of modernity. The examples quoted above, along with Hyde's warning, however suggest that things are significantly more complex: tricksters' role is not merely to bridge divergent phenomena but also to act as analytic separators; as keepers of the difference between heaven and earth, gods and humans, this world and the next, on so on. Tricksters, in short, are creatures of the symbolic, of language, of culture and their ambivalence comes from the slippery play of these domains' multiple meanings, not from their supposed promotion of a mystical all-in-one truth beyond all language and culture. When tricksters bridge gaps with language and enjoyment, they bear witness to a necessity to establish the same gaps first in order that language and enjoyment even come into existence; they exhibit a profound and radically modern acceptance of the ties the excess value possessed by culture and enjoyment holds not with an overly abundant otherworldly domain beyond rational apprehension but with the very impression of lack that befalls the world with that domain's departure from our world.

To summarise, the three folktales recorded by Janez Trdina in $19^{\text {th }}$ century within villages close to Slovenia's current capital might come across at first as relatively unique, yet most aspects of their odd content can be shown to possess parallels in folk or tribal tales collected by other researchers in other parts of the world. When examined together and compared with official biblical accounts of the same events and relations propagated by dominant religious institutions at the time of their recording, all three tales as well their counterparts from other parts of the globe exhibit a psychologically much more nuanced attitude towards reality than their Catholic counterparts. As demonstrated by the last myth recorded by Trdina, traditional thought is able to conceive even of the initial proximity of God and man, idealised by so many crucial myths of dominant religions, as an unpleasant state, preferring distance to God and working for pleasure as a framework for a blissful life. The world, similarly, is seen by traditional thought not as a rational creation of an analytically ordered whole but as a chance disruption of a rigid structure resulting in fragments providing enjoyment precisely as odd bits of a phantasmatic whole that cross over borders of established domains and attain their surplus value as much from the imagined whole as from their fragmentary status, and as much from their transgression as from the existence of established borders.

Creation itself is arguably conceived by traditional thought not as a wisely planned out and controlled act but as a relatively chance event, enabled by an internal split within the divine creator who must become distanced from His own self or in some other way

\footnotetext{
${ }^{15}$ Lewis Hyde, Ibid., p. 7.
} 
possessed by an inner abyss disabling Him from being fully conscious of Himself, if He wants to transgress borders and create new worlds. Finally, this creator as such, the great Other of the world, is consequently not seen as the carrier of an all-seeing gaze able to take in the whole of creation at once at any given time (as is the case with the God of modern monotheism at times reduced solely to this absolutely objective gaze, a single cyclopic eye of traditional European religious painting whose singularity prevents it from being conceived as an embodied, contingently fixed point of view); the God of Trdina's second myth is thus seen as the carrier of a fully embodied, bifocal point of view that is incapable of taking in the whole world at once and whose carrier is obliged to travel and exert Himself physically if $\mathrm{He}$ wishes to observe it; yet with the additional point that this gaze itself, rather than being conceived as looking at a whole actually existing independently from it (which would provide a place for an imagined meta-gaze that could view this phantasmatic whole), unwittingly creates what it is gazing at in that gaze's very wake, its creation constantly eluding it just beyond the horizon yet never existing anywhere beyond the actual gaze that creates it.

The use of the word 'horizon' in the previous sentence should serve to remind us of a relation between the problem of the gaze raised by the second story and the issue of difference opened by the third one: it is the horizon that enables the gaze, it is the reference point for any point of view, for any perspective, but the horizon is also the thin line simultaneously separating and connecting heaven and earth. In short, we could say that it is precisely this separation of elements (sky and earth, light and dark, to use examples traditional accounts share with the Bible) that enables us to see, to have a point of view and to symbolically grasp and construct reality.

All of these are complex and radically modern philosophical issues, which the official text of modern monotheisms that have been shaping European thought for millennia seemed much more ill-equipped to recognise than traditional belief systems, preferring to harbour instead idealistic fantasies about an all-seeing, morally superior and perfectly rational transcendence that abhors difference, is able to include all opposites in itself and resides invisibly beyond the horizon. Traditional thought, with its tales of unconscious, embodied gods creating chance fragments for our pleasure and pain while following an inexistent, forever eluding bit of their own creation into the sunset, seems to me much more interesting and worthy of analysis. As I conclude this essay, I hope that it has played its small part in convincing philosophers of the value in studying folk and tribal tales for a taste of their complex takes on the world, as well as ethnographers of the importance of keeping an open eye and mind for less-than-traditional explanations of their specific worldviews, including the new horizons they might open for European thought in the future. 


\section{Primerjalna filozofska analiza razlike, smrti, pogleda in veselja v treh slovenskih stvaritvenih mitih 19. stoletja}

\section{Izar Lunaček}

Članek si za izhodišče jemlje tri zgodbe o stvarjenju, ki jih je v vaseh, ki ležijo na današnjem slovenskem ozemlju v 19. stoletju zapisal Janez Trdina in preko njihove primerjave $\mathrm{z}$ miti iz drugih delov sveta (predvsem na osnovi dela komparativnega mitologa Zmaga Šmitka) razvija filozofsko podlago za globlje razumevanje tako njihove vsebine kot arhaične misli na splošno. Pri prvem mitu tematizira razmerje med sublimnim stvarnikom in materialnostjo ustvarjenega sveta ter vlogo nezavednega v stvarjenju, ob drugem se poglobi v koncepte relativizma in statusa božjega pogleda, pri tretjem pa se ukvarja predvsem z zamislijo o odsotnosti Boga v svetu ter posledičnimi nadlogami smrti, dela in trpljenja, kakor nanjo gleda krščansko Sveto pismo na eni in arhaična mitologija na drugi strani. S to razdelitvijo članek upa na doprinos tako h globljemu konceptualnemu razumevanju mitološkega materiala znotraj etnologije kot k večji pozornosti do etnografskih sporočil v filozofiji. 